\section{ERNESTO NAZARETH:}

\section{A PROJEÇÃO DOS GRUPOS DE CHORO AO PIANO}

revistamúsica | Vol. 18, n.2 |

pp. 46-65 | dez. 2018

\section{ANDRÉ REPIZO MARQUES}

Instituto de Artes UNESP |

andre_repizo@hotmail.com

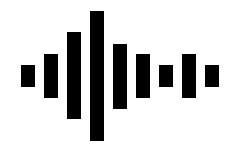

\section{ERNESTO \\ NAZARETH:}

PROJECTING THE CHORO

ENSEMBLES ON THE PIANO

\section{RESUMO}

Este artigo tem como objetivo analisar a música de Ernesto Nazareth sob a ótica do choro. Ao observar elementos musicais comuns à obra de Ernesto Nazareth e aos grupos de choro, notamos a relação de troca e desenvolvimento mútuo entre ambos. Com foco nesses elementos musicais (harmonia; melodia; condução do baixo e motivos rítmicos), utilizando ferramentas de análise musical e revisão bibliográfica acerca da obra de Nazareth, buscamos encontrar direções para guiar a fruição e construção de uma performance.

\section{PALAVRAS-CHAVE}

\section{Ernesto Nazareth. Choro. Interpretação.}

\section{ABSTRACT}

This paper aims to analyze the musical repertoire by Ernesto Nazareth in connection with the choro style. Observing some common grounds between Ernesto Nazareth's music and the choro ensembles, we noticed the existence of an exchange and mutual development among them. Focusing on some structural elements (harmony, melody, bass conduction and rhythmic motives), with the help of music analytical tools and bibliographic research on the work of Nazareth, we search for some hints to hearing and performing his music.

\section{KEYWORDS}

Ernesto Nazareth. Choro. Performance. 


\title{
Ernesto Nazareth: a projeção dos grupos de choro ao piano
}

\author{
ANDRÉ REPIZO MARQUES \\ Instituto de Artes UNESP | andre_repizo@hotmail.com
}

\section{A música de Ernesto Nazareth}

Este artigo parte da diversidade de interpretações da obra de Ernesto Nazareth, cuja performance tem sido realizada tanto por pianistas eruditos como por rodas de choro. Essa diversidade de interpretações nos inspira a levantar algumas questões: quais são as ferramentas auditivas e interpretativas de que dispomos para fruição das músicas de Nazareth? Tais ferramentas existem em função da obra escrita ou do ambiente, da instrumentação ou do meio social em que a música é tocada? Como era atuação de Nazareth como pianista e compositor? Como era a prática musical dos pianistas desse período? O que nós temos que observar na história da música popular urbana do Rio de Janeiro para abordar essa música? Como ocorreu a troca de informações entre Nazareth e os músicos das rodas de choro?

Em princípio, podemos reduzir essas questões classificando as músicas do compositor como eruditas ou populares, e assim teremos critérios pré-estabelecidos para a solução destes questionamentos. Se considerarmos as peças no sentido estrito da música erudita, o que já nos proporia um problema de abordagem devido ao panorama social da época no Brasil, do conceito de música erudita desse período, e ao histórico da recepção dos gêneros regionais em voga à época em que as músicas de Nazareth eram compostas, poderemos escolher nos ater exclusivamente à partitura, à tradição interpretativa e à técnica pianística, sobretudo aquelas herdadas da música romântica europeia. Se as considerarmos como peças populares, correremos o risco de abarcar um sem número de gravações e formações instrumentais que interpretam as músicas de Nazareth, e, por consequência, acabar por escolher uma interpretação difusa com a justificativa de que, em música popular há maior liberdade de possibilidades interpretativas, incluindo a improvisação.

Ainda em relação a essa questão, o pesquisador Cacá Machado afirma que a "música de Nazareth não se realizava nem como tradição (ou não-tradição) da música erudita nacional, nem como música popular folclórica. E, de certo modo, o próprio Nazareth incorporou esse não-lugar à sua música" (MACHADO, 2007, p. 27). Poderíamos interpretar o "não lugar" como a fronteira entre erudito e o popular, que se encontrava em constante mudança no período da belle époque carioca devido à troca de informações e entrelace cultural entre as classes sociais. O pesquisador Hermano Vianna (2007, p. 113) observa nessa troca de informações uma modificação constante do panorama cultural da cidade, que renegocia todas as fronteiras. Como exemplo, podemos observar os saraus e pequenos concertos realizados nas casas da elite carioca do final do século XIX, pois eles "eram recheados de ligeiras polcas (assim como valsas, schottischs e mazurcas) 
entre as peças de destaques dos famosos compositores europeus" (VIANNA, 2007, p. 28). Desse modo, tanto o "lugar" como o "não lugar" são imaginados pelos críticos, teóricos, historiadores e, principalmente, pelas elites sociais, que são aquelas que detêm as narrativas (históricas, documentações, jornais, imprensa) - nas quais tal fronteira sequer precisa existir. O "não lugar" pode ser simplesmente a falta de lugar em um cenário musical mais propenso ao entrelace de estilos e gêneros musicais que à divisão entre erudito e popular.

Portanto, esse "não lugar", rico em criatividade, em que encontramos o surgimento de gêneros musicais urbanos, configura um labirinto a ser percorrido pelos intérpretes da obra de Nazareth, havendo a possibilidade de existência de vários caminhos e várias saídas.

$\mathrm{O}$ artigo tem como proposta procurar desvendar algumas dessas questões, utilizando os elementos musicais comuns à obra de Ernesto Nazareth e aos grupos de choro. Por meio desses elementos (harmonia; melodia; condução do baixo e motivos rítmicos) e utilizando ferramentas de análise musical e revisão bibliográfica acerca da obra de Nazareth, buscamos encontrar direções para guiar a fruição e construção de uma performance.

Procuramos elencar alguns aspectos que legitimam afirmações como a do musicólogo Mozart Araújo: "Nazareth fez de seu piano uma espécie de síntese da música dos chorões" (ARAÚJO apud SALLES, 1994, p. 88). Temos dois vieses distintos a respeito dessa troca de informação e conhecimento entre os músicos cariocas no final do século XIX e início do século XX. O primeiro viés nos leva a pesquisar características dos grupos de choro na música de Nazareth e os elementos musicais que o compositor extraiu dos grupos que se dedicavam a tocar o repertório das danças de salão de origem europeia em voga no final do século XIX e início do século XX, apresentando como sua base instrumental a flauta, o violão e o cavaquinho. Segundo o pesquisador Henrique Cazes, Nazareth trabalhou na tradução pianística dos chorões, ou seja, trouxe os elementos do choro para o piano (CAZES, 1998, p. 32).

No segundo viés, podemos supor que tenha existido o processo inverso, ou seja, os chorões é que foram buscar elementos musicais no piano de Nazareth. O que nos leva a essa suposição são os elementos que viriam a ser característicos do pandeiro da década de 1920, mas já existentes nas músicas de Nazareth compostas no período anterior à presença do instrumento nos regionais de choro; pois, como afirma Prof. Dr. Alexandre Zamith Almeida (1999), o pandeiro foi adotado definitivamente naquela década e ganhou destaque só na década de 1930. Em outras palavras, a ideia rítmica do pandeiro no choro havia aparecido antes, na síncopa cheia. Tal síncopa, grosso modo, é o conjunto de quatro semicolcheias que devido às alturas diferentes e acentos resultantes geram uma síncopa (MACHADO, 2007, p. 52).

Ainda nesse sentido, dando respaldo a essa ideia, o pesquisador Gabriel Rezende (2014, p. 287) nos informa, em sua tese de doutorado, que Jacob do Bandolim (1919-1969) considerava Ernesto Nazareth como um dos pilares do Choro, ou seja, o desenvolvimento do Choro devia, em grande parte, ao legado musical deixado por Nazareth. Podemos refletir e observar melhor essa via de mão dupla quando ouvimos as músicas de Nazareth interpretadas por grupos de choro. Dentre elas destacamos: a gravação de "Brejeiro" por Altamiro Carrilho, João Donato e Conjunto 
em 1949 pela gravadora Star; a gravação de "Matuto" por Benedito Lacerda, Pixinguinha e conjunto pela RCA Victor em 1950; e em 1952, a gravação de oito músicas de Nazareth por Jacob do Bandolim também pela RCA Victor. Dessa forma, aborda-se adiante a música de Nazareth pelos dois pontos de vista que essa via de mão dupla oferece.

\section{Análise da projeção dos grupos de choro ao piano}

Alguns autores, tais como Mário de Andrade (1928), Bruno Kiefer (1982) e Brasilio Itiberê (1946), foram específicos ao citarem os instrumentos que Ernesto Nazareth possa ter utilizado como referência na projeção dos grupos de choro ao piano e em quais músicas essas alusões foram feitas. As análises a seguir têm como objetivo investigar e compreender como ocorreu a síntese do grupo de choro em algumas obras para piano de Nazareth. De maneira resumida, podemos dizer que o cavaquinho é reduzido, no piano, à função rítmica, o violão à função harmônica e contrapontística, e a flauta, à função melódica.

Dessa forma, veremos nos parágrafos e figuras a seguir tais alusões na música de Nazareth, segundo esses autores. Com suas palavras, poderemos observar a mesma linha de raciocínio da pianista Sônia Rubinsky que, em entrevista, relata que ao construir uma interpretação ao piano é possível construir camadas sonoras, e "se você pensa em camadas, forçosamente você tem que pensar em quem estaria tocando isso. [...] Então, estou sempre pensando: que instrumento faria isso? [...] Quem estaria tocando esse baixo? Quem estaria tocando esse do meio? E se tivesse tocando esse do meio, como sairia?” (RUBINSKY, 2017, p. 140).

Mário de Andrade, em seu artigo de 1928, cita quais foram os instrumentos que inspiraram Nazareth, não com a exatidão que a pianista Sônia Rubinsky sugere em sua imaginação, mas sim de forma genérica. Nesse caso, Andrade faz referência ao oficleide, ao violão e à flauta, e também informa em quais músicas ocorrem tais alusões:

Porém careço de voltar ainda ao caráter instrumental de Ernesto Nazareth pra uma observação. Se serviu do piano. Pois bem a obra delle é pianística como o que. Pianística mesmo quando se inspirando no instrumental das serestas, funcções, chôros e assustados reflecte o officleide, o violão, e especialmente a flauta que nem no trio do Atrevido e no Arrojado quasi inteiro. Então numa obraprima sapeca, o Apanhei-te Cavaquinho, este e a flauta numa capoeiragem orchestica de espírito inigualável, rivalizam de personalidade, ambos maxixeiros de fiança, turunas no remeleixo e cueras na descaída (ANDRADE, 1928).

No trecho acima, Andrade ressalta a flauta como um dos instrumentos de inspiração para Nazareth. Pode-se notá-la em elementos musicais expressos na partitura, dentre os quais ressaltamos três: 1) o contorno melódico, geralmente construído com semicolcheias, que para maior fluidez da frase exige leveza do toque; 2) a ornamentação; e 3) o registro. Para ilustrar essa alusão ao fraseado da flauta, Andrade cita as músicas "Apanhei-te Cavaquinho", "Arrojado" e o trio do "Atrevido" (Figuras 1, 2 e 3). 


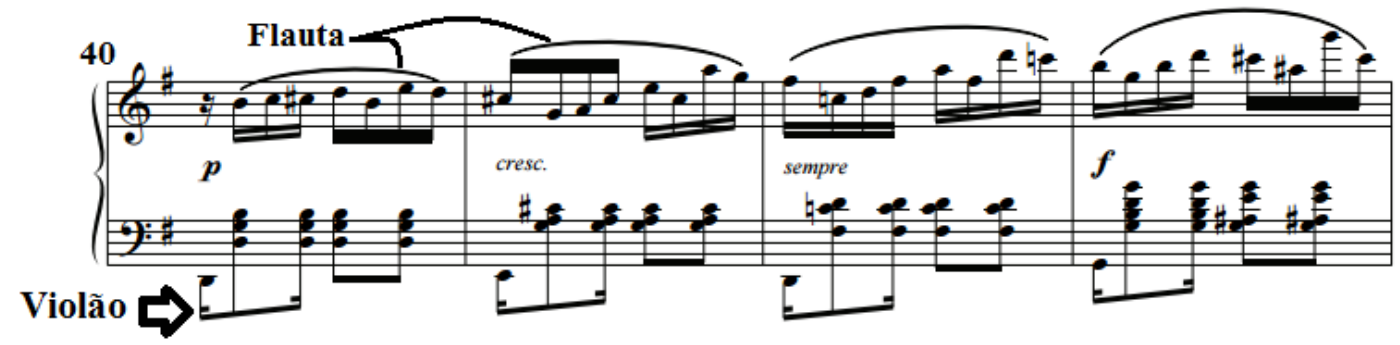

Figura 1: Trio do tango Atrevido (c. 40-43) (NAZARETH, 1913).

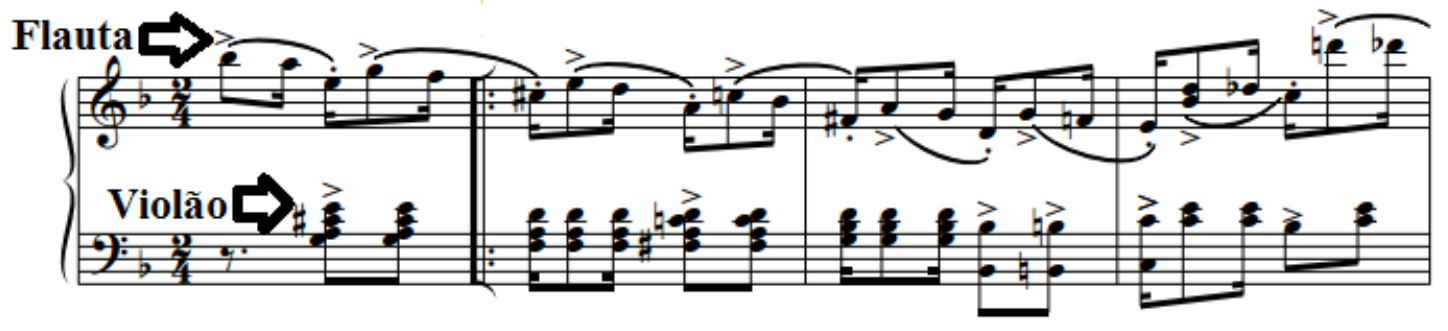

Figura 2: Samba Arrojado (c. 1-4) (NAZARETH, 1921).

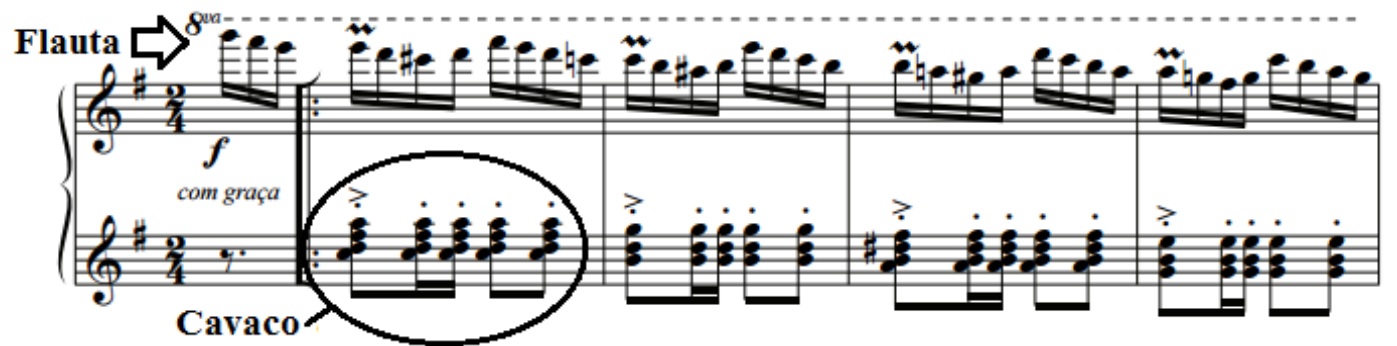

Figura 3: Apanhei-te Cavaquinho (c. 1-4) (NAZARETH, 1914).

Ainda sobre a música “Apanhei-te Cavaquinho”, Luiz Antonio de Almeida (2004), biógrafo de Nazareth, afirma que o compositor se apropriou de uma expressão da época, que era usada quando alguém "era pego em alguma situação embaraçosa”. Então neste momento dizia-se: “Ah! Apanhei-te cavaquinho!" O biógrafo concorda com Andrade ao afirmar que Nazareth usou a flauta na mão direita, e acrescenta a ideia de que o compositor aproveitou a ideia do título e simulou o cavaquinho na mão esquerda, o que de fato se pode constatar pela correspondência do registro e do ostinato do instrumento na mão esquerda.

Outro autor que também segue essa linha de raciocínio é o pesquisador Bruno Kiefer em seu livro História da Música Brasileira (1982). Nesse livro, o autor cita a alusão do violão em “Odeon” (1909), e enfatiza a escrita pianística de Nazareth.

[...] frequentemente Nazareth compõe para piano à moda de certos instrumentos populares. É a mão direita imitando a flauta, é a esquerda imitando o violão (como no tango Odeon, por exemplo), e assim por diante. Não obstante, o compositor escreve sempre muito pianisticamente (KIEFER, 1982, p. 123).

Bruno Kiefer associa a seção A (c. 1-17) de "Odeon” ao violão, devido à construção melódica no registro médio/grave do piano com predominância de graus conjuntos. Não podemos 
descartar a possibilidade dessa seção evocar o oficleide ou até mesmo o bombardino, instrumentos com a tessitura próxima à da melodia construída e que, além de compor as bandas e fanfarras deste período, também tocavam em grupos de choro com a função contrapontística típica das "baixarias" no choro. O pesquisador Mozart Araújo (1972, p. 26) também cita esses dois instrumentos ao se referir à maneira alusiva como Nazareth compôs.

Ainda neste sentido, o que nos leva a supor que Nazareth talvez não tenha evocado o violão são as primeiras gravações de choro, realizadas por volta de 1907, em que o violão não era usado à maneira como é utilizada hoje no gênero (CAZES, 1998, p. 17). Os primeiros violonistas a tocar o violão sete cordas no choro de que se tem registro foram a dupla Tute (1886-1957) e China (1888-1927; Otávio Littleton da Rocha Vianna, irmão de Pixinguinha), e Dino Sete Cordas (1918-2006; Horondino José da Silva). O último introduziu uma nova maneira de tocar o instrumento no choro, com frases sincopadas e maior interação com a melodia. No trecho abaixo, da dissertação de mestrado de Pellegrini, Análise dos acompanhamentos de Dino Sete Cordas em samba e choro, podemos observar o comportamento musical desses violonistas:

Tute foi um violonista "pé-de-boi", pela sua firmeza no acompanhamento, o que proporcionava ao solista mais segurança e liberdade na interpretação. Esse estilo 'marcado' foi a primeira base sobre a qual foram se formando os violonistas de choro do início do século XX. Depois de Tute, quem modificou radicalmente a linguagem do violão de sete cordas ao ponto que conhecemos hoje como procedimento típico nesse instrumento foi Dino Sete Cordas. Além da marcação do tempo em semínimas e colcheias, Dino acrescentou frases sincopadas que se comunicavam mais intimamente com a melodia principal (PELLEGRINI, 2005, p. 44).

"Odeon" data de 1909, ou seja, período em que o violão ainda não se comportava à maneira como é utilizado atualmente. Portanto, o violão melódico que tendemos a encontrar, sobretudo o de sete cordas, na seção A (c. 1-17) de "Odeon" não condiz com as fontes levantadas acima.

A associação de Odeon com o violão é encontrada não apenas no livro de Kiefer, mas também no do pesquisador Cacá Machado. Nele, o autor disserta acerca das músicas "Tenebroso" e "Odeon" - vejamos neste trecho abaixo:

\begin{abstract}
Como em Odeon, é a melodia do baixo a voz principal: um típico acompanhamento das 'baixarias' cromáticas do violão, até mesmo em sua divisão rítmica. Aliás, parece uma partitura escrita para violão, pois a montagem fechada dos acordes e a posição rítmica em que esses se colocam em relação ao baixo cantábile são extremamente naturais para a digitação no instrumento (no violão, os acordes não podem ser muito abertos por uma dificuldade técnica que se limita aos quatro dedos da mão esquerda do violonista; no piano, ao contrário, os acordes podem ter maior abertura porque são montados com as duas mãos). Portanto, Nazareth escreveu literalmente uma peça violonística para o piano. A engenhosidade do compositor faz com que a peça também soe muito bem no piano, de modo que, como vimos em Odeon, Tenebroso surge como mais um exemplo para demonstrar que Nazareth parece ter criado um paradigma de escrita pianística para a estilização dos instrumentos das rodas de choro (MACHADO, 2007, p.167-168).
\end{abstract}

Tanto na música "Tenebroso" como em "Odeon" o autor está descrevendo a escrita da seção A, em que em seus argumentos poderia ser uma peça escrita para violão. Apesar desses argumentos, e sendo a escrita pianística de Nazareth bastante idiomática, são necessários alguns ajustes para que outros instrumentos possam tocá-las, tais como troca de tonalidade e de registro. 
Desta forma, o arranjo de “Odeon” lançado em 1991 pelo violonista Raphael Rabello (19621995) é um exemplo de ajuste para melhor performance da peça ao violão.

Raphael Rabello optou por transpor o tom original uma terça menor acima, passando para o tom de Mi menor. Essa mudança favorece a escrita idiomática do violão, cujas seis cordas soltas estão relacionadas com a tonalidade escolhida: duas cordas $\mathrm{Mi}$ - que é a tônica -, as cordas Lá e $\mathrm{Si}$ - que são a subdominante e a dominante deste centro tonal, respectivamente -, e as cordas Sol e Ré - que são a relativa maior e sua dominante, respectivamente (NUNES e BORÉM, 2014, p. 100).

Ainda podemos observar a projeção dos grupos de choro em "Odeon" por meio das associações rítmicas, com o cavaco, e de registro com a flauta. A seção B (c. 18-34) contém a síntese do trio completo. A Figura 4 mostra a distribuição das referências sonoras dos instrumentos na peça.

A

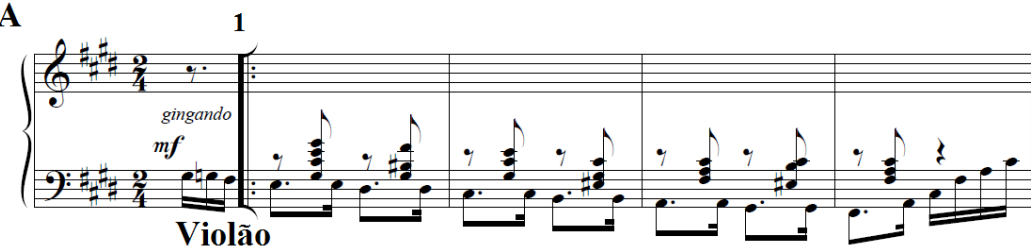

B

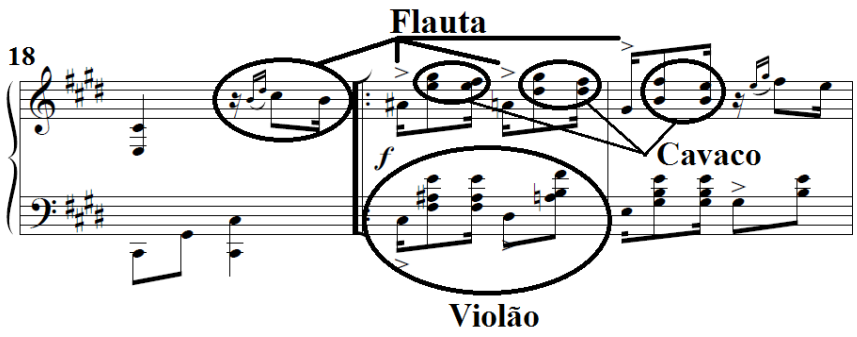

C

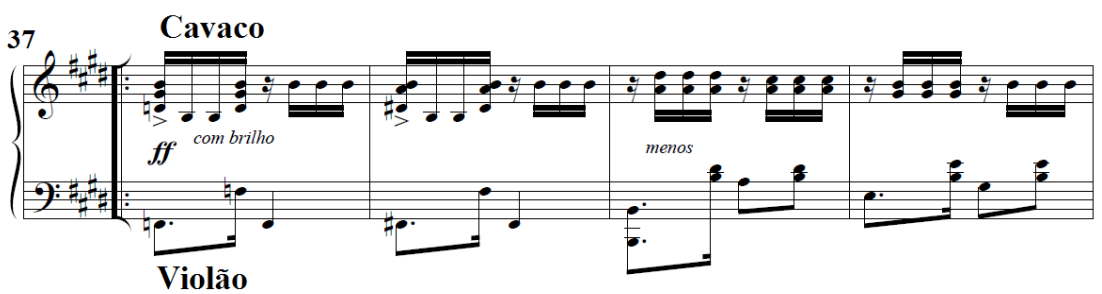

Figura 4: Referências sonoras do violão, cavaquinho e flauta nas partes A (c. 1-17), B (c. 18-34) e C (c. 3755) de Odeon.

Se voltarmos um pouco às reflexões iniciais, e a elas acrescentarmos essas análises, poderemos vislumbrar outra perspectiva. Dessa forma, como visto, Robervaldo Linhares Rosa nos diz de forma mais abrangente sobre a música de Nazareth: "Em sua forma de tocar, pode-se perceber que era evocada ao piano a sonoridade dos instrumentos chorões, como o violão, o cavaquinho e a flauta" (ROSA, 2014, pp. 90-91). Ou seja, aqui ele nos diz que a forma de tocar evocava os instrumentos chorões, e não a escrita. Portanto, se em alguns momentos observamos na escrita uma alusão ao violão, podemos inferir que seja possível que a forma de tocar, como a articulação, seja influenciada pela sonoridade do violão. 
Nessa linha de raciocínio, uma característica do violão, sobretudo o de sete cordas, é o recurso da "nota fantasma". Esse recurso interpretativo consiste em dar uma função percussiva para notas com altura definida, que, quando tocadas ao violão, são levemente abafadas para que se ouça seu caráter percussivo, minimizando suas qualidades melódicas ou harmônicas. Sendo a "nota fantasma" uma questão interpretativa, não escrita, podemos levantar a hipótese do uso de tais notas com função rítmica na escrita de Nazareth ao reconhecermos as alusões ao violão. Estariam implícitas "notas fantasmas" em trechos em staccato como nos exemplos abaixo.

Nas Figuras 5 e 6, as notas circuladas corresponderiam às "notas fantasmas", em que há a função rítmica. Na parte $\mathrm{C}$, onde supomos a menção do cavaco também há a utilização de notas com função rítmica, neste caso não podemos considerar como "nota fantasma", pois o cavaco pode ou não abafar essas notas, portando ressaltamos apenas sua função rítmica.

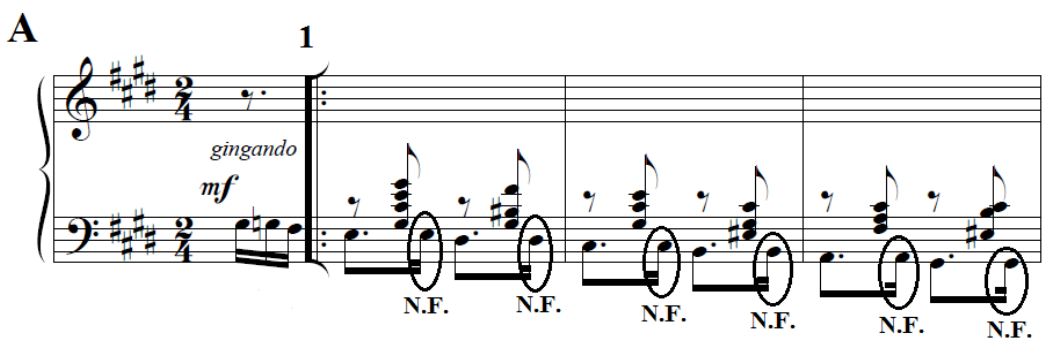

C

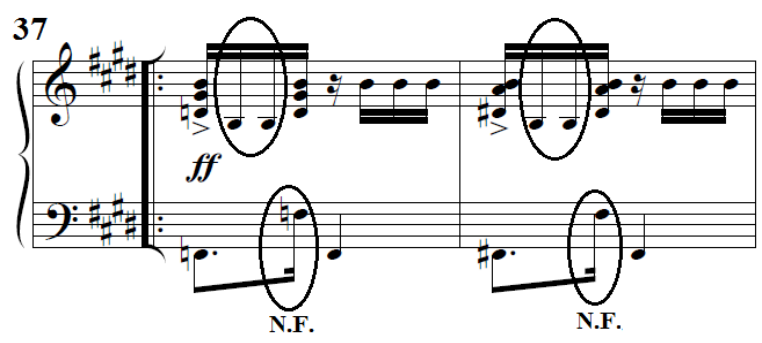

Figura 5: Primeiros compassos da parte A e C de "Odeon" (NAZARETH, 1913). Notas circuladas corresponderiam às "notas fantasmas", em que há a função rítmica.

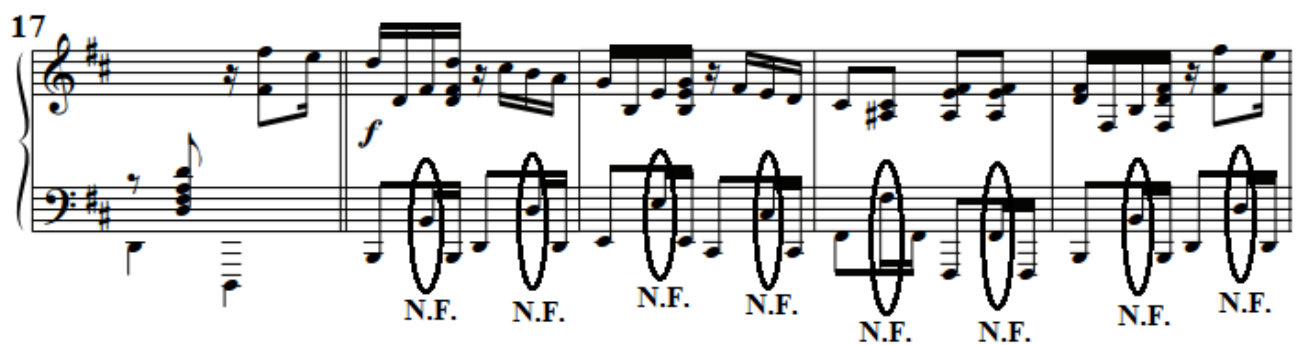

Figura 6: Tango "Tenebroso" (NAZARETH, 1913) (c. 17-21). Notas circuladas corresponderiam às "notas fantasmas", em que há a função rítmica.

Também observamos na música "Tenebroso" (Figura 6), mais especificamente na seção B, notas com função rítmica em que há a possibilidade de se executar um leve staccato aludindo desta forma a "nota fantasma" do violão. Essa música foi dedicada "ao bom e velho amigo" Sátyro Lopes de Alcântara Bilhar (1860-1926), violonista, compositor popular e "chorão", considerado "grande especialista do instrumento" (VASCONCELOS, 1964, p. 170). Ele foi amigo íntimo de 
Nazareth e, segundo sua sobrinha Julita Nazareth Siston, frequentava as reuniões na casa do compositor nas quais a grande atração era a música.

Quando tio Ernesto recebia os amigos em casa, era sempre uma festa. Até os vizinhos logo se faziam convidados e, por vezes, traziam os seus próprios convidados. Estas reuniões eram muito concorridas. Mas não que apresentassem fartura nos comes e bebes. Não, absolutamente. A atração era a música. (...) Seu Bilhar era muito amigo de tio Ernesto. Ele era meio gago, chamava tio Ernesto de b...Ernesto. Ele também tocava um pouco de piano, mas muito pouco. Era engraçado quando ele ia para o piano, anunciava a sua "última criação" e começava a tocar... Mas, o que ele tocava era sempre uma mesma e velha música, conhecida de todos nós. Aí, o pessoal lá de casa passou a chamar a tal música de "A nova do Bilhar". (Julita Nazareth Siston. Entrevista concedida a Luiz Antônio de Almeida. Rio de Janeiro, s/d.)

Pelo fato da primeira parte do tango "Tenebroso" (c.1-16) ter a melodia na região grave do piano (Figura 7), o pesquisador Luiz Antônio de Almeida (2016) afirma ser "uma alusão ao violão do Bilhar ou, segundo alguns, à sua voz rouca”.
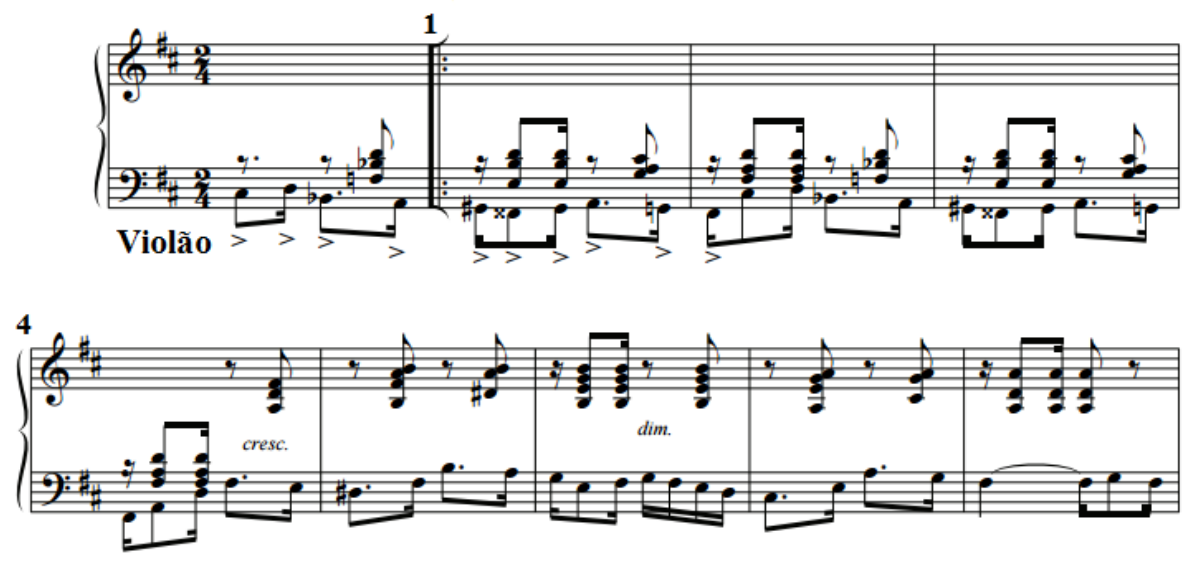

Figura 7: Tango “Tenebroso" (NAZARETH, 1913) (c. 1-8). Alusão ao violão com melodia na região grave do piano.

É possível observar a menção da condução harmônica e rítmica do violão em grande parte da obra de Nazareth. Células rítmicas da mão esquerda, como no Trio do Tango "Atrevido" e no Samba "Arrojado", como já visto nas figuras anteriores, permeiam as músicas do referido compositor. Já Brasilio Itiberê nos mostra outra característica do violão em Nazareth, em que a “mão esquerda faz saltos difíceis, numa estilização violenta do violão como nos tangos 'Labirinto' e “Carioca”" (ITIBIRÊ, 1946, p. 317).

"Difíceis" pela distância intervalar em um curto espaço de tempo para o deslocamento da mão sobre o teclado (Figura 9 e 10), em que também observamos na Figura 8 a dificuldade oferecida no salto da mão esquerda nas apojaturas circuladas. A "estilização violenta", que Itiberê se refere, talvez seja pela segunda parte da música Labirinto (c. 19-34), na qual a mão esquerda toca oitavas acentuadas com a indicação de expressão “com ímpeto" (Figura 8). 

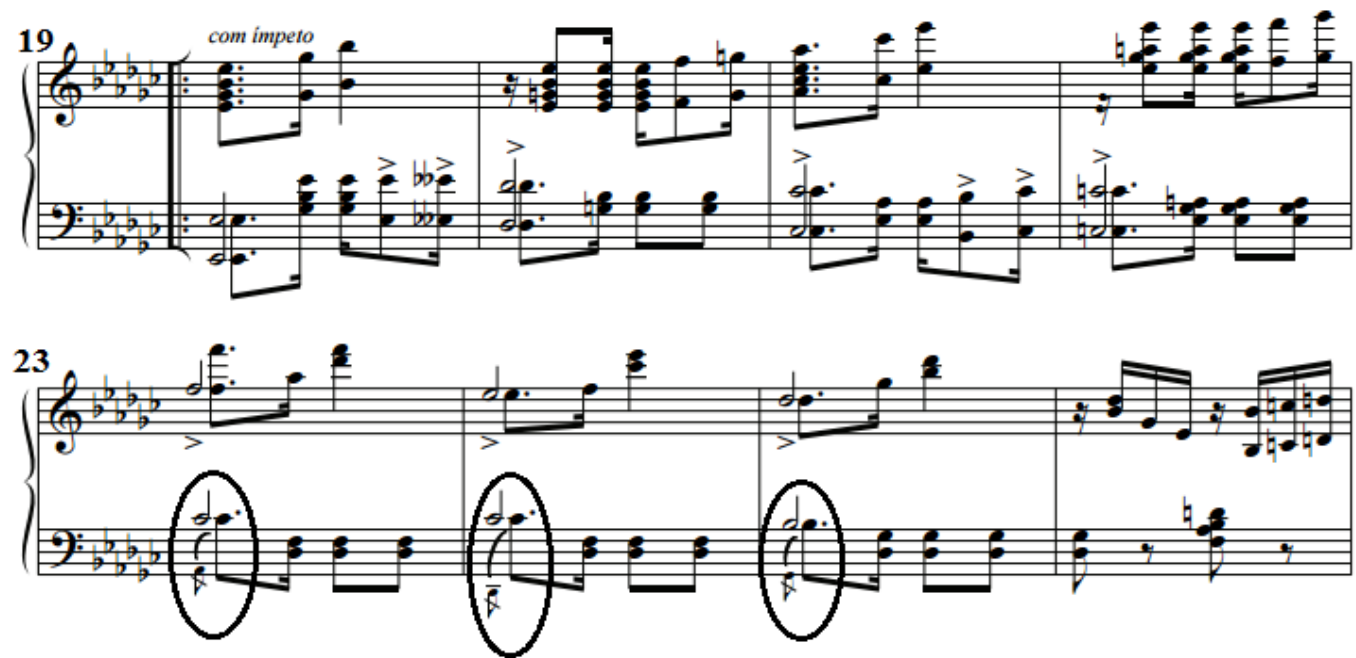

Figura 8: Tango "Labirinto" (c. 19-26) (NAZARETH, 1917). Dificuldade do salto da mão esquerda nas apojaturas circuladas.

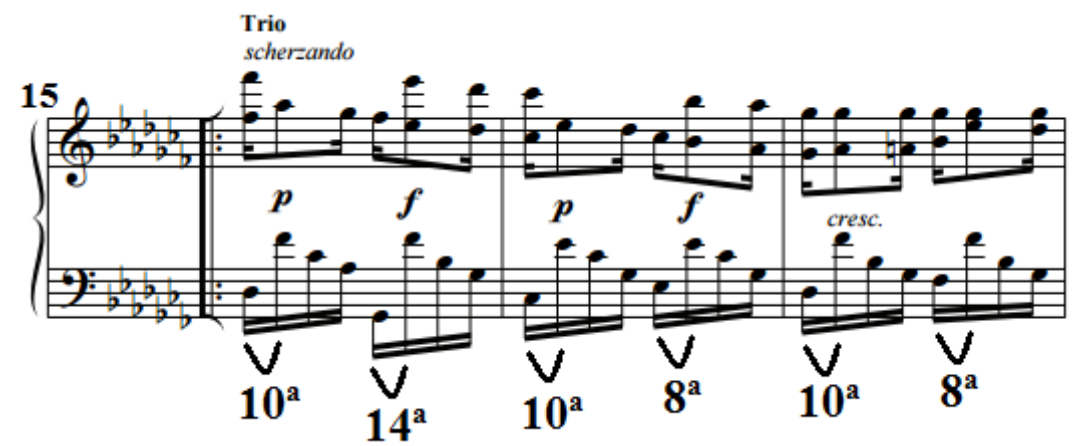

Figura 9: Trio do Tango "Labirinto" (c. 15-17) (NAZARETH, 1917). Distância intervalar dos saltos da mão esquerda.

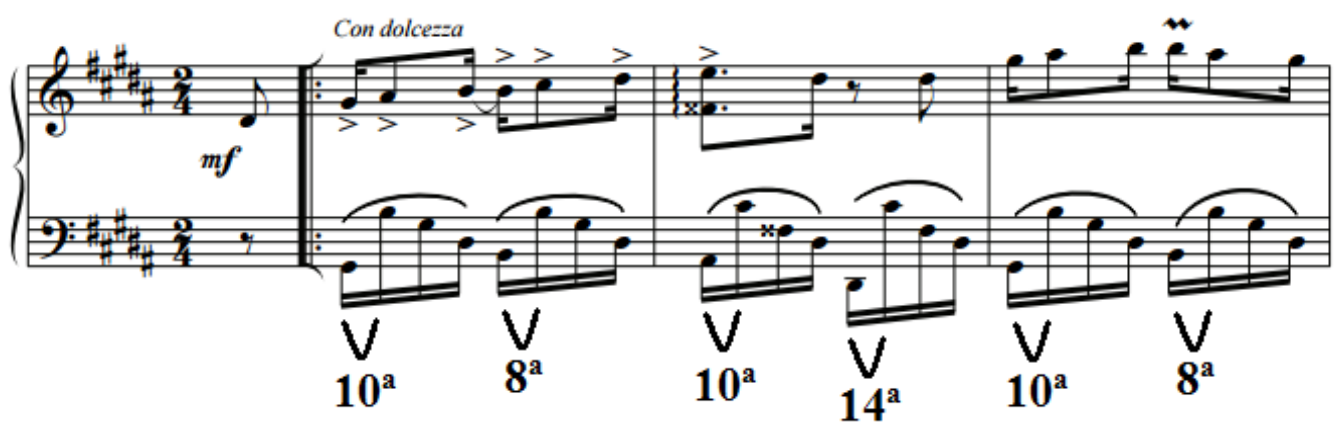

Figura 10: Tango “Carioca” (c. 1 -3) (NAZARETH, 1913). Distância intervalar dos saltos da mão esquerda.

Supomos que Brasilio Itiberê (1946) tenha feito referência ao violão nessas duas músicas pela condução harmônica ser melódica e arpejada. Na primeira parte de "Labirinto" (c. 1-16, Figura 11), por exemplo, o contorno melódico faz menção ao fraseado do violão, principalmente no primeiro compasso, em que a condução da frase descendente leva ao Ré bemol, comportamento típico do violão de sete cordas. 


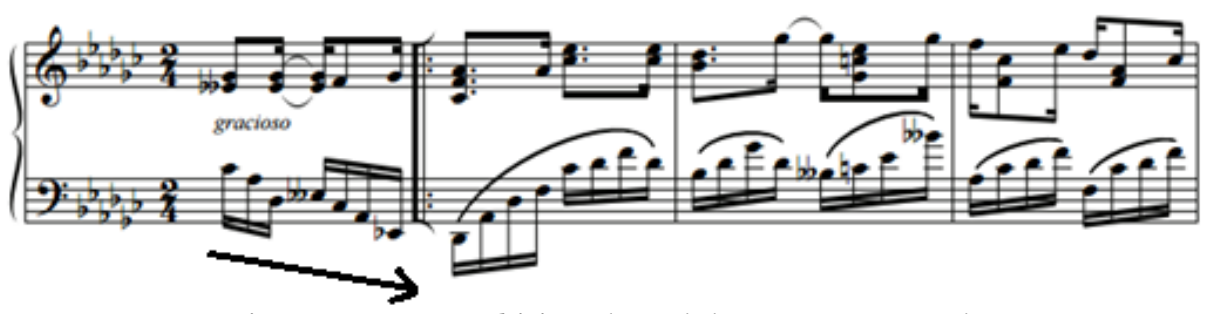

Figura 11: Tango Labirinto (c. 1-4) (NAZARETH, 1917).

A condução harmônica arpejada do trio do tango "Labirinto" (c. 38-53) e da primeira seção do tango "Carioca" (c. 1-16) - exemplificadas nas figuras 9 e 10 - apontam para ideia do violão dedilhado. Essa condução arpejada é um elemento composicional que permeia a obra de Nazareth - também podemos encontrá-la nas polcas "Beija-flor" (1884) e "A Fonte do Lambary" (1888).

A polca "Beija-flor" é classificada por Cacá Machado (2007, p. 47) como uma polca-salão, devido aos acordes em staccato e a ressonância dos acordes de "modo pianístico ornamental e encorpado". Em seu livro, Machado apresenta outros exemplos, além desse, em que a construção entre diferentes planos contrastantes resulta em uma textura singular na obra de Nazareth.

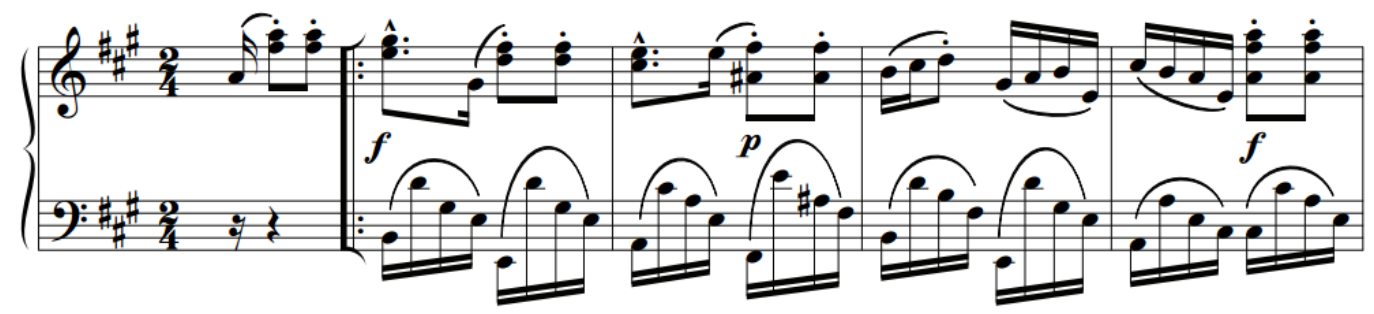

Figura 12: Polca “Beija-flor” (c. 1-4) (NAZARETH, 1884).

A classificação que Cacá Machado dá à polca da figura acima remete-nos à música de salão e lembra-nos que, além da referência aos instrumentos populares, Ernesto Nazareth compunha sob grande influência da música romântica europeia. Esse desenho rítmico-melódico de acompanhamento da mão esquerda, que Itiberê (1946) associa ao violão, é característico da música de salão. Encontramos um exemplo dele na Sonata para piano op. 90 de Beethoven (1770-1827) que, apesar de não ser música de salão, tendo sido escrita em 1814, reflete paradigmaticamente esse padrão.

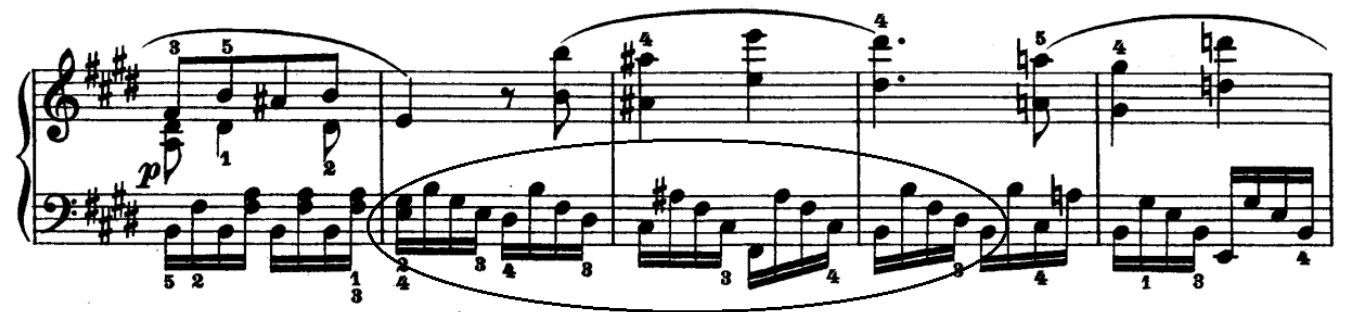

Figura 13: Sonata op. 9o, $2^{\circ}$ mov. (c.15-19) (BEETHOVEN, 1814). O círculo indica desenho rítmicomelódico de acompanhamento da mão esquerda.

Entendemos que esse desenho rítmico-melódico de acompanhamento da mão esquerda, presente na música de Nazareth e provavelmente no acompanhamento de outros pianistas e 
pianeiros que atuaram nesse período, era tocado de maneira diferente da apresentada no exemplo acima. Assim como o chorão "amolecia" as melodias das polcas, provavelmente essa figura rítmica também pode ganhar outra intenção musical. Portanto, a alusão que Itiberê (1946) faz ao violão não exclui o fato desse acompanhamento ser de música de salão, mas indica que há outra maneira de tocá-lo.

Inferimos que a interpretação do motivo rítmico em semicolcheias, como na polca "Beijaflor" (c. 1-4, Figura 12), também faça alusão ao pandeiro. Para não cometermos um anacronismo musicológico, temos que compreender que essa alusão pode ter ocorrido nas interpretações de pianistas após a década de 1930, pois o pandeiro só ganhou destaque dentro do choro a partir desta década, na Era do Rádio, em que os grupos de choros passaram a ser chamados de "conjuntos regionais" (SEVERIANO, 2013, p.35). Portanto, Ernesto Nazareth não projetou o pandeiro em suas composições, visto que esse desenho rítmico-melódico de acompanhamento tem origem na música de salão, porém a maneira de tocá-lo após a década de 1930 pode ter incorporado outras perspectivas.

A alusão ao pandeiro pode ser feita pela direção melódica configurada na semicolcheia. As últimas três semicolcheias do grupo de quatro direcionam-se melodicamente para a cabeça do próximo tempo. De maneira análoga, o pandeiro exerce a mesma direção agógica, embora não apresente alturas definidas. Na tradição oral, tal direção é transmitida de maneira onomatopeica pelos músicos da seguinte forma: Ca-ra-ca Chá-ca-ra-ca Chá.

Como exemplo dessa associação, a figura abaixo mostra a mão esquerda dos quatro primeiros compassos da Polca "A fonte do Lambary" (1888), em que as semicolcheias foram divididas em graves (círculos vermelhos), agudos (azul) e médios (preto). A divisão foi feita dentro de um gama de sons limitada entre as regiões médio grave do piano.

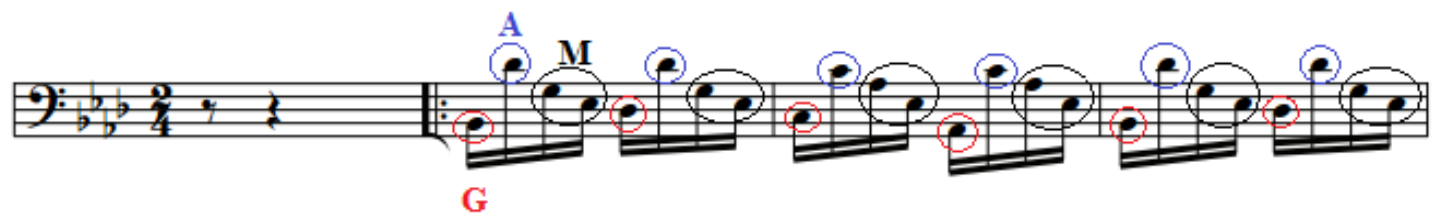

Figura 14: Polca "A Fonte do Lambary” (c. 1-4) (NAZARETH, 1888). Graves (círculos vermelhos), agudos (azul) e médios (preto).

Assim como o piano, o pandeiro tem a capacidade de sintetizar as funções rítmicas, ou seja, em um único instrumento é possível escutar os sons graves (polegar), médios (tapas) e agudos (platinelas).

O pesquisador Cacá Machado também encontra outro desenho rítmico "análogo ao movimento do pandeiro, que nas rodas de choro, conduz o ritmo em semicolcheias, escolhendo as acentuações do tempo fraco" na polca "Cruz! Perigo!" (1879, c. 1-16). Porém, nesse caso, isso ocorre por meio do contraste de acentuações entre as semicolcheias. Na figura abaixo, podemos 
observar a mão direita preenchendo todo o compasso com semicolcheias, e a melodia é construída por meio das acentuações da primeira nota de cada grupo de semicolcheias.

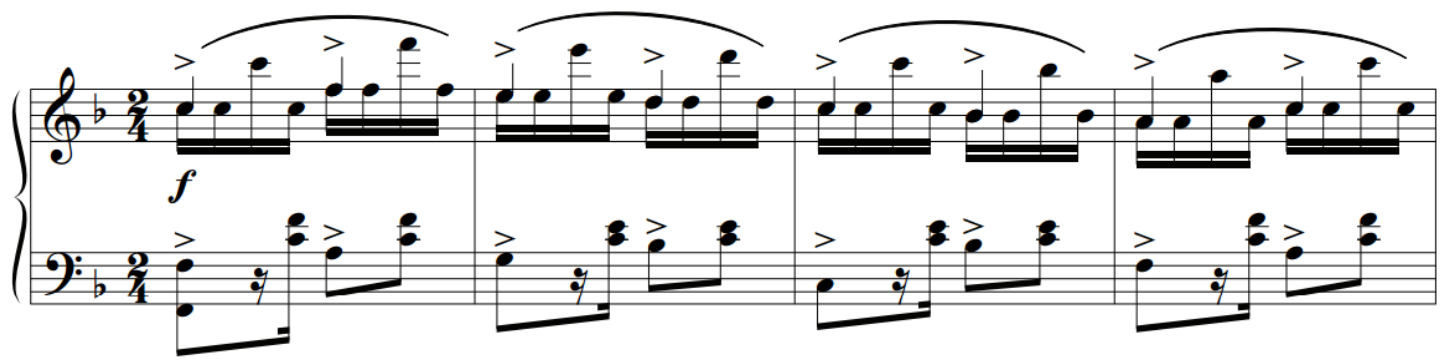

Figura 15: polca “Cruz! Perigo!” (1879, c. 1-4).

De acordo com Cacá Machado,

Esse motivo da mão direita está construído sob a figura rítmica de semicolcheias que repetem a mesma nota, repicada e rebatida, já que a terceira semicolcheia de cada grupo é tocada na sua oitava superior. O primeiro plano é feito pelo rebatimento das oitavas entre a primeira e terceira nota do grupo de semicolcheias, que acentuam, respectivamente, um tempo forte e um tempo fraco, numa duração rítmica que, vista separadamente, é representada por duas colcheias. O segundo plano é formado pelas notas da mesma oitava repicadas pelo espaço deixado pela nota oitavada do terceiro tempo do grupo das semicolcheias, cuja duração rítmica, isolada, desenha a figura da síncopa característica (brasileirinho). (MACHADO, 2007, p. 52)

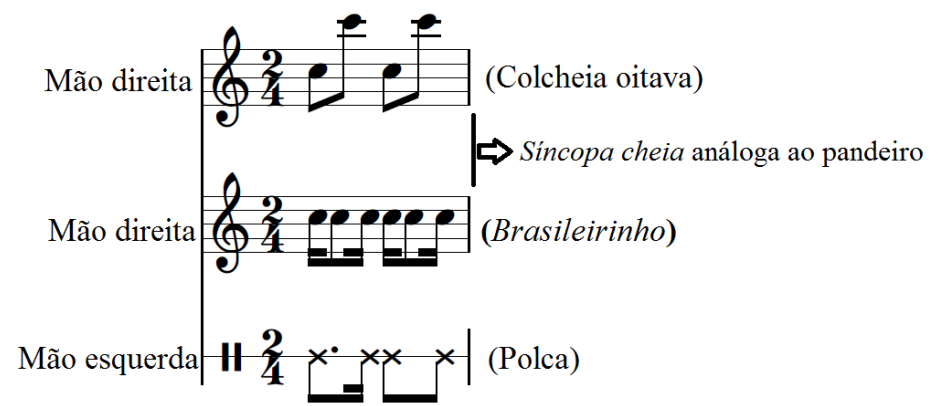

Figura 16: ilustração musical da síncopa cheia (MACHADO, p. 52, 2007).

Cacá Machado encontra nesse procedimento composicional, a partir da construção de planos que resulta numa textura específica (como na Figura 16), a principal característica de Ernesto Nazareth (MACHADO, p. 54, 2007).

Com esses pontos de vista sobre a alusão ao pandeiro na obra de Nazareth, concluímos que ela é possível por meio de interpretações musicais e teóricas após a década de 1930. Nessa última referência ao instrumento, com a síncopa cheia, observamos não só a alusão possível em uma interpretação, mas também uma ideia musical desenvolvida na música de Nazareth que é utilizada na maneira de tocar o pandeiro no choro.

Dessa forma, podemos observar por meio dos textos desses pesquisadores mencionados acima a projeção dos instrumentos populares da roda de choro nas músicas de Ernesto Nazareth. A consciência desta projeção pode influenciar diretamente a interpretação de um pianista ao ler uma partitura, pois ao reconhecer a alusão de determinados instrumentos, o músico tomará 
decisões de articulação, respiração e fraseado para evocar a sonoridade idealizada desses instrumentos.

\title{
3. Ernesto Nazareth nos grupos de choro
}

Como mencionamos no começo do artigo, há um segundo viés acerca da projeção dos grupos de choro na obra de Nazareth, em que podemos notar o processo inverso; ou seja, foram os chorões que buscaram elementos musicais no piano de Nazareth, e assim distribuíram entre os instrumentos do grupo de choro as ideias de rítmicas, melódicas e harmônicas de sua música. Corroborando com essa ideia, Jacob do Bandolim (1918-1969) considerava Nazareth como um dos pilares do choro (REZENDE, 2014, p. 287), ou seja, o desenvolvimento do choro devia-se em grande parte ao legado musical deixado por Nazareth.

Neste sentido, podemos refletir a respeito dessa ideia e observar essa via de mão dupla quando ouvimos as músicas de Nazareth interpretadas por grupos de choro. Nessas interpretações, verificamos justamente aquele "processo inverso", ou seja, os grupos de choro adotam as composições de Nazareth para piano em seu repertório.

O Prof. Dr. Alexandre Zamith Almeida, em sua dissertação de mestrado, mostra-nos como se dá essa via de mão dupla:

\begin{abstract}
Como instrumento intérprete de choros, o piano atuou como uma redução do grupo chorão, podendo realizar - à sua maneira - a melodiosidade da flauta, as harmonias e baixos dos violões e a rítmica do cavaquinho. Desta forma, exerceu uma troca mútua com os músicos de choro, incorporando e traduzindo as suas características instrumentais elementos tipicamente chorões e, ao mesmo tempo, oferecendo aos grupos de choro uma enorme quantidade de obras que, escritas originalmente para piano, foram muito bem adaptadas à formação instrumental típica do choro. No segundo caso, encontram-se como exemplos característicos obras de Ernesto Nazareth como os tangos Odeon e Brejeiro que, incorporados pelos chorões, tomaram-se peças imprescindíveis ao repertório de qualquer grupo regional. (ALMEIDA, 1999, p. 105)
\end{abstract}

O historiador Jairo Severiano corrobora Almeida: "Ernesto Nazareth, que enriqueceu o repertório do choro com várias obras-primas, mas não é propriamente um chorão, sendo antes um estilizador do gênero" (SEVERIANO, 2013, p. 37). Seria impossível encontrarmos um registro histórico que informe quando, quem e onde exatamente ocorreu a adoção das músicas de Nazareth pelos grupos de choro, pois o que temos são declarações genéricas acerca do assunto, além das gravações disponíveis em disco.

Como exemplo, Joel Nascimento (1937; bandolinista que teve contato pessoal com Jacob) em uma entrevista ao Prof. Dr. Almir Côrtes Barreto (UNIRIO), afirma que essa adoção das músicas de Nazareth pelos grupos de choro foi feita após as interpretações de Jacob do Bandolim (1918-1969): "O Jacob foi quem introduziu Ernesto Nazareth no choro, o chorão conhece Nazareth através de Jacob com as reduções que ele fez" (NASCIMENTO apud BARRETO, 2006, p. 2). Notamos nessa afirmação um comportamento típico dos músicos populares, cujo conhecimento se dá pela oralidade sem o cuidado de averiguar tais informações. 
Nessa fala, o bandolinista ignora as gravações anteriores as de Jacob do Bandolim. As primeiras gravações de Jacob com as músicas de Nazareth foram em abril de 1952: nessa ocasião, gravou quatro discos 78 RPM pela gravadora RCA Victor. Em julho 1955, os quatro discos foram compactados em um só pela mesma gravadora, com o título: Jacob Revive Músicas de Ernesto Nazaré (a grafia Nazaré, e não Nazareth, de fato foi utilizada no disco). Nesse disco foram gravadas as músicas "Odeon", "Saudade", "Turbilhão de beijos", "Atlântico", "Tenebroso", "Faceira", "Nenê" e "Confidências".

Podemos elencar algumas gravações que antecedem o ano de 1952 para constatar que não foi Jacob do Bandolim quem introduziu as composições de Nazareth nos grupos de choro. Dentre elas, destacamos a gravação feita pela Casa Edison (Odeon) da música "Está chumbado" (zon-Ophone/X-1.055) em 1902. Quem tocou essa primeira composição de Nazareth registrada em disco foi a Banda do Corpo de Bombeiros, regida por Anacleto de Medeiros (1866-1907). Também ressaltamos outros registros, tais como: a gravação feita pela Casa Edison (Odeon), do tango "Brejeiro" ("O sertanejo enamorado") em 1905, com letra de Catullo da Paixão Cearense e cantado por Mário Pinheiro; a gravação pela Columbia Record da música "Bambino" com o Grupo Bahianinho (Bandolim e conjunto), feita entre 1908-1910, aproximadamente; algumas obras de Nazareth, que em 1910 foram gravadas por diversas bandas, como Banda do Corpo de Bombeiros do Rio de Janeiro, Banda Columbia, Banda da Casa Faulhaber, Banda Escudeiro, entre outras; duas gravações feitas aproximadamente em 1912, uma da música "Bambino" pelo Grupo Sustenidos (Bandolim e conjunto) na Odeon Record, e a outra da música "Brejeiro" com o Grupo Bahianinho na Columbia Record; duas gravações, pela Casa Edison (Odeon) da polca "Apanheite, cavaquinho" em 1916, uma com o Grupo O Passos no Choro, e outra com a Orquestra Odeon; em 1928 duas de suas peças são gravadas por Francisco Alves e Vicente Celestino, os dois cantores de maior destaque da época no Brasil; Altamiro Carrilho (1924-2012), João Donato (1934) e Conjunto gravam "Brejeiro" em 1949 pela gravadora Star; Benedito Lacerda (1903-1958), Pixinguinha (1897 - 1973) e conjunto gravaram a música "Matuto" pela RCA Victor em 1950; e em 1952, Garoto (1915-1955) gravou a música "Perigoso" pela gravadora Odeon .

As gravações mencionadas acima comprovam não ter sido Jacob do Bandolim quem trouxe Nazareth para o repertório do choro. Uma evidência clara, até pelo nome do conjunto, é a gravação de "Apanhei-te, cavaquinho" em 1916, com o grupo O Passos no Choro.

Ainda nesse sentido, notamos o fato da Banda do Corpo de Bombeiros, regida por Anacleto de Medeiros, dentre outras bandas mencionadas anteriormente, terem em seu repertório músicas de Nazareth. Esse fato implica em duas evidências claras de que a música de Nazareth já circulava pelos chorões dessa época (a primeira gravação feita por uma Banda foi em 1902). Uma delas é a regência de Anacleto de Medeiros, que segundo Henrique Cazes (p. 27, 1998) é um dos pilares do Choro. A outra é a ligação entre as bandas e os músicos que participavam dos grupos de choro. Essa ligação se dava pelo processo de educação musical que ocorria nas bandas, que em sua maioria tinham como regentes chorões. Desta forma, a cultura chorística era introduzida aos músicos. 
Além das bandas tocarem Nazareth, também observamos que alguns cantores gravaram o compositor. Essa evidência nos mostra que as melodias de Nazareth eram conhecidas não só pelos grupos instrumentais, mas também por cantores. Esse fato corrobora a ideia que as melodias de Nazareth, tão conhecidas ao ponto de virarem canções, fossem tocadas pelos chorões da época ("Brejeiro" foi gravado em 1905, com letra de Catullo da Paixão Cearense).

Ainda nessa direção, ressaltamos as últimas gravações mencionadas acima: nelas estão os músicos Altamiro Carrilho, Benedito Lacerda, Pixinguinha e Garoto. Este elenco de chorões, juntamente com Jacob do Bandolim, certifica-nos que a obra de Nazareth está no repertório dos chorões.

Além das gravações citadas acima, encontramos o registro histórico da presença dos tangos de Nazareth no repertório dos chorões do Morro de Santo Cristo. Luiz Edmundo, memorialista e historiador do Rio de Janeiro que exerceu a atividade de literato e jornalista do então Correio da Manhã da belle époque, conta histórias e fala dos ambientes por ele vividos na virada do século XIX-XX em sua obra O Rio de Janeiro do meu tempo (2003). Em seu capítulo Morro de Santo Antônio, o autor narra os costumes musicais do período e afirma ouvir Nazareth no choro:

De dois gêneros são as serenatas que se fazem entre nós: a serenata de cantigas e a que se denomina choro. Na primeira avulta a voz humana ferindo a melodia, subalternizando todo o conjunto harmônico da massa instrumental. No choro o caso é diferente, a voz humana não se escuta. Soam, apenas, os instrumentos gemedores, soturnos, em adágios plangentes que, na época, o sofrimento é a flor que se cultiva... No repertório dos chorões estão as valsas langorosas de Francisca Gonzaga, os sincopados tangos de Ernesto Nazaré, de J. Cristo e Assis Pacheco, schottischs de Nicolino, Aurélio Cavalcanti, Costa Júnior e Sinfonia Ornelas, músicas patéticas, adocicadas, que os instrumentos supriam melosamente, a escorrer ternura, provocando suspiros, e saudades (EDMUNDO, 2003, p. 166).

O pesquisador Cacá Machado faz uma observação sobre o trecho acima que nos leva a olhar de forma panorâmica as tradições musicais de origem popular do século XX:

(...) sua crônica demarca acertadamente duas tradições que, ao longo do século XX, vão definir a música urbana de origem popular: a) a serenata e a modinha, que contribuíram para a formação da canção do modo que a conhecemos hoje em dia; b) a música instrumental, que em sua evolução incorporou vários gêneros: música dos barbeiros, polca, schottischs, valsa, mazurca, tango brasileiro, maxixe, enfim, gêneros dançantes que forneciam o mote para a prática musical dos chorões (MACHADO, 2007, p. 33).

Outro registro histórico é a descrição de Ernesto Nazareth feita por Alexandre Gonçalves Pinto, carteiro e músico amador que escreveu o livro $O$ Choro, principal documento sobre a prática instrumental da música popular urbana desse período:

Ernesto Nazareth, espírito superior de aprimorada educação, música de primeira àgua, foi brilhante sem jaça, que bem poucos o iguariam no seu saber.

As Harmonias feitas por elle eram um hymno do céo.

Toucou em grandes e nobres salões, onde sabia portar-se como gentleman dotados da família, onde tocasse fazia logo camaradagem, ficando logo íntimo, como se fosse de um conhecimento longo. Tocou em muitas festas, em que também se achavam os grandes chorões como elle, que também fizeram seus esplendores nos bailes desta capital como seriam: J. Christino, Costinha, Chiquinha Gonzaga, já por nós descriptos, Paulinho Sacramento, e todos os outros que não me vêm à mente, pois foram em grandes quantidades destes chorões da velha guarda, que infelizmente já não existem. (PINTO apud MACHADO, 2007, pp. 36-37) 
Podemos notar na descrição dessa testemunha que Nazareth era considerado um "chorão da velha guarda" pelos músicos populares, e o coloca ao lado de músicos que compartilhavam a mesma habilidade. No entanto, podemos encarar esta narrativa como uma hipérbole da figura de Nazareth, pois é conhecido que o referido compositor era uma pessoa com características introspectivas e não uma pessoa "que fazia logo camaradagem, ficando logo íntimo, como se fosse de um conhecimento longo". O depoimento de Nair Carvalho, filha de uma ex-aluna de Nazareth, corrobora essa linha de raciocínio:

\begin{abstract}
Nazareth era austero, sóbrio, encerrando-se em sua torre de marfim, pouco comunicativo, reservado e como alheado das coisas externas. Se acaso alguma aluna sua ousava "insinuar-se" para o seu lado, procurando "flertar" ou namorá-lo, era o suficiente para que ele não mais voltasse a sua casa, tal como aconteceu a uma jovem viúva de rara beleza, a quem conheci (cujo nome do falecido esposo, figura até hoje em uma das ruas principais de Jacarepaguá). (NAIR CARVALHO, depoimento por escrito enviado para Luiz Antônio de Almeida. RJ, 8 de julho de 1984).
\end{abstract}

Portanto, ao lermos o texto de Alexandre Gonçalves Pinto, notamos seu apreço por Nazareth por meio de seus elogios e certo exagero nas palavras. Não vamos levar a discussão aos detalhes da sua narrativa, pois nosso objetivo é evidenciar a relação de Nazareth com o choro, os músicos e a linguagem musical desse meio.

Além desses registros, também há evidências da relação de Nazareth com instrumentistas do universo do choro, como Viriato Figueira da Silva (1851-1883), "flautista que junto com Calado, Patápio Silva e, posteriormente, Pixinguinha, criou uma tradição desse instrumento, desafiando as fronteiras da chamada música erudita e popular na cultura musical brasileira" (MACHADO, 2007, p. 25). A primeira apresentação pública do jovem Nazareth foi ao lado de Viriato, conforme a Revista de Bellas Artes publicada em 13 de março de 1880:

\begin{abstract}
Realizou-se na segunda-feira 8 do corrente concerto de Mlle. Luiza Saucken, com o generoso concurso de amadores e artistas. (...) Da parte instrumental encarregaram-se os senhores Silveira, Madeira e Nazareth ao piano, os Srs. Barnardelli na rabeca, Viriato na flauta, e Horacio Lemos, no clarinete. Todos se houveram bem merecendo especial menção os Srs. Silveira e Viriato. Pelos tempos que correm pode-se dizer afoutamente que foi este um bom concerto. (Revista Bellas Artes apud MACHADO, 2007, p. 25).
\end{abstract}

Portanto, observamos que, desde o início de sua carreira, Nazareth (nessa época com 17 anos) já se relacionava com músicos mais velhos que ele, como Viriato (nessa ocasião com 29 anos). Importante notarmos que sua relação com o flautista foi além desta ocasião mencionada acima: entre 1880 e 1881, os dois músicos realizaram uma disputa entre títulos de suas músicas. Viriato perguntou: “Caiu, não disse?” (1880), e Nazareth respondeu: “Não caio n’outra!” (1881) (2007, p. 25).

Não temos como ter a precisão de como funcionava a relação entre os músicos nesse período, como eram suas conversas e discussões sobre algum assunto musical; no entanto, por meio dessas informações, podemos afirmar que a interação entre os músicos existia. Como vimos acima, Nazareth tocou com Viriato, em outro momento houve a disputa de títulos, e provavelmente ambos ouviam ao outro. Nesse sentido, Nazareth afirma ouvir Viriato, Calado e Paulino Sacramento para compor, nas palavras de Brasílio Itiberê: 
Certa vez meu amigo Oscar Rocha, melômano e folclorista e um dos homens que melhor conhecem a vida e a obra de Nazareth, perguntou-lhe como é que ele tinha chegado a compor os seus tangos, com esse caráter rítmico tão variado [...] Nazareth respondeu com simplicidade que ele ouvia muito as polcas e os lundus de Viriato, Calado, Paulino Sacramento e sentiu desejo de transpor para o piano a rítmica dessas polcas-lundu (ITIBERÊ apud SANDRONI, 2001, p. 78).

Ou seja, antes da era do rádio, para se ouvir música era necessário que ela fosse executada ao vivo. O pesquisador de música brasileira Hermano Vianna (2007, pp. 114-115), informa-nos que Ernesto Nazareth frequentava o Cine Palais para ouvir o grupo de Pixinguinha e Donga, os Oito Batutas. Este grupo foi convidado para tocar na sala de espera do cinema pelo gerente do estabelecimento Isaac Frankel antes do Carnaval de 1919. Nesse momento, Nazareth foi público incentivador dos Oito Batutas, e em 1950 foi a vez de Pixinguinha prestigiar Nazareth, com a gravação da música "Matuto" pela RCA Victor.

Podemos observar, por meio dos dados apresentados acima, ainda que superficialmente, como se dava a relação de troca entre os músicos cariocas. Dessa forma, podemos concluir que Ernesto Nazareth teve uma relação de troca com o universo do choro. Nessa via de mão dupla, observamos em suas composições elementos que fazem alusão às características instrumentais de um grupo de choro e transportam todo esse universo sonoro ao piano. Em contrapartida, também vemos os músicos chorões interpretando Nazareth e evidenciando o diálogo entre o piano, nesse período um instrumento associado com a elite, e os grupos populares.

\section{Conclusão}

A partir dos pontos apresentados e estudados, observamos a música de Ernesto Nazareth sob o viés do choro projetado ao piano e sob o olhar da música de Nazareth como influenciadora na construção do choro. Dessa forma, notamos o desenvolvimento mútuo dos músicos cariocas do final do século XIX e início do século XX que consequentemente estabeleceram juntos o gênero musical choro.

Dessa forma, podemos inferir que a projeção dos grupos de choro ao piano dá-se por meio da grafia, em que podemos constatar visualmente os elementos musicais comuns, e por meio da interpretação ao piano que acentua a referência de instrumentos do choro como cavaquinho, flauta e violão.

Os elementos musicais comuns à obra de Ernesto Nazareth e aos grupos de choro são evidentes na utilização de fraseados que se assemelham aos que encontramos nas flautas, na condução rítmica do cavaco, que de semelhante modo é feita em grande parte da obra do referido compositor pela mão esquerda do pianista, e em conduções de baixo que podem se referir ao violão, ao oficleide ou até mesmo o bombardino.

Como vimos, essa intersecção que se configura nas composições de Nazareth dá-se devido ao desenvolvimento do choro e sua maneira de tocar feita concomitantemente pelos pianeiros e instrumentistas que frequentavam então as rodas de choro na belle époque carioca. Coube a músicos como Ernesto Nazareth sistematizar e registrar essa prática musical em partituras. 
Dessa maneira, observamos uma via de mão dupla ao ouvimos as músicas de Nazareth interpretadas por grupos de choro. Segundo Henrique Cazes, o caminho dessa música é curioso, pois "da livre adaptação das partituras de piano trazidas da Europa, surgiu a música dos chorões" (CAZES, 1998, p. 36). Nazareth traduziu essa ambiência para o piano, ou seja, trouxe a música de volta ao piano. Com as gravações dos grupos de choro, as composições voltam para as rodas de choro.

\section{Referências}

ALMEIDA, Alexandre Zamith. Verde Amarelo em Preto e Branco: as impressões do choro no piano brasileiro. Dissertação (Mestrado em Artes). Campinas/SP: UNICAMP, 1999.

ARAUJO, Mozart de. Ernesto Nazareth. Revista Brasileira de Cultura. Rio de Janeiro: Conselho Federal de Cultura/MEC Ano IV, Número 14, pp. 13-28, out./dez. de 1972.

BARRETO, Almir Côrtes. O Estilo Interpretativo de Jacob do Bandolim. Dissertação (Mestrado em Música) Campinas/SP: UNICAMP, 2006.

BEETHOVEN, Ludwig van. Sonaten für Klavier zu zwei Händen, Bd.2. Leipzig: C.F. Peters, n.d.(ca.1920). Plates 10543, 10555-56. Sonata op. 90 (1814).

CAZES, Henrique. Choro: do quintal ao municipal. São Paulo: Ed. 34, 1998.

EDMUNDO, Luiz. O Rio de Janeiro do meu tempo. Brasília: Senado Federal, Conselho Editorial. Edições do Senado Federal, Volume 1. 2003.

ITIBERÊ, Brasílio. Ernesto Nazaré na Música Brasileira. In: Boletim Latino-Americano de Música. Rio de Janeiro: Ano V/6, abril/1946, pp. 308-321.

KIEFER, Bruno. História da Música Brasileira dos primórdios ao início do século XX. (3a. ed. revista). Porto Alegre: Editora Movimento, 1982.

MACHADO, Cacá. O enigma do homem célebre: ambição e vocação de Ernesto Nazareth. São Paulo: Instituto Moreira Salles, 2007.

MARQUES, André Repizo. Interpretações da música de Ernesto Nazareth: pianistas, pianeiros e os chorões. Dissertação. (Mestrado em Música) Instituto de Artes. São Paulo: UNESP, 2017.

NAZARETH, Ernesto. Você bem sabe [Polca-Lundu]. Rio de Janeiro: editora Arthur Napoleão, chapa $n^{0}$ 5790 (AN5790), 1878.

Todo Nazareth - Obras Completas. Organização: Tiago Cury e Cacá Machado. São Paulo: Água-Forte Edições Musicais. 2011. A Fonte do Lambary (1888).

Todo Nazareth - Obras Completas. Organização: Tiago Cury e Cacá Machado. São Paulo: Água-Forte Edições Musicais. 2011. Apanhei-te Cavaquinho (1914).

Todo Nazareth - Obras Completas. Organização: Tiago Cury e Cacá Machado. São Paulo: Água-Forte Edições Musicais. 2011. Arrojado (1921).

Todo Nazareth - Obras Completas. Organização: Tiago Cury e Cacá Machado. São Paulo: Água-Forte Edições Musicais. 2011. Atrevido (1913).

Todo Nazareth - Obras Completas. Organização: Tiago Cury e Cacá Machado. São Paulo: Água-Forte Edições Musicais. 2011. Batuque (1913).

Todo Nazareth - Obras Completas. Organização: Tiago Cury e Cacá Machado. São Paulo: Água-Forte Edições Musicais. 2011. Carioca (1913).

Todo Nazareth - Obras Completas. Organização: Tiago Cury e Cacá Machado. São Paulo: Água-Forte Edições Musicais. 2011. Confidências (1913).

Todo Nazareth - Obras Completas. Organização: Tiago Cury e Cacá Machado. São Paulo: Água-Forte Edições Musicais. 2011. Labirinto (1917).

Todo Nazareth - Obras Completas. Organização: Tiago Cury e Cacá Machado. São Paulo: Água-Forte Edições Musicais. 2011. Odeon (1909). 
. Todo Nazareth - Obras Completas. Organização: Tiago Cury e Cacá Machado. São Paulo: Água-Forte Edições Musicais. 2011. Tenebroso (1913).

NUNES. Alvimar Liberato; BORÉM. Fausto. O Arranjo e o improviso de Raphael Rabello sobre Odeon de Ernesto Nazareth. Per Musi, Belo Horizonte, n.30, pp. 98-113, 2014.

PELLEGRINI, Remo Tarazona. Análise dos acompanhamentos de Dino Sete Cordas em samba e choro. Dissertação (Mestrado em Música). Campinas/SP: Unicamp, 2005.

PINTO, Alexandre Gonçalves. O Choro. Rio de Janeiro: Funarte, 1978.

REZENDE, Gabriel Sampaio Souza Lima. O problema da tradição na trajetória de Jacob do Bandolim: comentários à história oficial do choro. Tese (Doutorado em Música). Campinas/SP: UNICAMP, 2014.

ROSA, Robervaldo Linhares. Como é bom poder tocar um instrumento: pianeiros na cena urbana brasileira. Goiânia: Cânone Editorial, 2014.

SALLES, Vicente. Rapsódia Brasileira. Fortaleza: Universidade Estadual do Ceará, 1994.

SANDRONI, Carlos. O feitiço decente: transformações do samba no Rio de Janeiro (1917-1933). Rio de Janeiro: Jorge Zahar, 2001.

SEVERIANO, Jairo. Uma história da música popular brasileira. $3^{\text {a }}$. ed. São Paulo: Ed. 34, 2013.

VASCONCELOS, Ary. Panorama da Música Popular Brasileira. São Paulo: Ed. Livraria Martins, 1964.

VIANNA, Hermano. O Mistério do Samba. 6. ed. Rio de Janeiro: Jorge Zahar/Ed. UFRJ, 2007.

\section{Gravação em CD}

JACOB REVIVE MÚSICAS DE ERNESTO NAZARÉ. Ernesto Nazareth (Compositor). Jacob Pick Bittencourt (Intérprete, Bandolim). Horondino José da Silva (Intérprete, Violão de sete cordas). James Tomás Florence (Intérprete, Violão de seis cordas). LP 10”. Grav. RCA Victor, 1955.

RABELLO, Raphael. Odeon, para violão solo. In: Raphael Rabello \& Dino 7 Cordas. CD de áudio. Número de série 8493211; reeditado pela Kuarup com o número KCD113. Rio de Janeiro: Caju Music, 1991.

\section{Internet}

ALMEIDA, Luiz Antônio. Ernesto Nazareth, Vida e Obra. Disponível em < http://ernestonazareth150anos.com.br/Chapters/index/12 > acesso em 04/08/2016.

ANDRADE, Mário de. Ernesto Nazareth. Ilustração Brasileira. Rio de Janeiro: Sociedade Anonyma "O Malho", Junho 1928, Ano 9 número 94. Disponível em <http://ernestonazareth150anos.com.br/files/uploads/texts/text_12.pdf> acesso em 18/06/2015.

CARVALHO, Nair. Depoimento por escrito enviado para Luiz Antônio de Almeida. Rio de Janeiro, 8 de julho de 1984. Disponível em: < http://www.ernestonazareth150anos.com.br/Chapters/index/146>. Acesso em 23/02/2017.

Documentário sobre Ernesto Nazareth exibido em 19/03/2004 no canal STV (Sesc TV). Disponível em < https://www.youtube.com/watch?v=pB9JhsVLz8Y> Acesso em 01/09/2015.

SISTON, Julita Nazareth. Entrevista concedida à Luiz Antônio de Almeida. Rio de Janeiro, s/d. Disponível em: < http://ernestonazareth150anos.com.br/Chapters/index/345 >. Acesso em 04/o8/2016. 